\title{
THE EFFORTS TO IMPROVE STUDENT LEARNING RESULTS USING COOPERATIVE LEARNING MODELS OF TALKING CHIPS TYPES IN BIOLOGICAL DIVERSITY MATERIALS IN CLASS X MIA SENIOR HIGH SCHOOL 2 MEDAN ACADEMIC YEAR 2018/2019
}

\author{
Rizki Annisa Ritonga $^{1 *}$, Zulkifli Simatupang $^{1}$, and Nopita Sitompul ${ }^{2}$ \\ ${ }^{1}$ Department of Physics Faculty of Mathematics and Natural Sciences, Medan State University \\ ${ }^{2}$ Science Department Faculty of Mathematics and Natural Sciences, Medan State University \\ St. Williem Iskandar Psr. V Medan Estate, Medan, Indonesia, 20221 \\ * \\ annisaritongarizky@gmail.com
}

Accepted: November $11^{\text {th }}, 2019$. Published: November $26^{\text {th }}, 2019$

\begin{abstract}
This study aims to determine the increase in learning outcomes and student activities through the use of the Talking Chips type cooperative learning model on the subject matter of Biodiversity in class X MIA1 Medan 10 Senior High School T.P. 2018/2019. The research method is classroom action research, and the subject of this research is 35 students in class MIA1 as many as 35 people. The instrument used in the study was a test of learning outcomes in the form of pretest and posttest questions as many as 30 questions and student activity observation sheets. The results showed, based on the learning outcomes of the first cycle, the average score of pretest 40.6 increased to 68.6 in the posttest. In the second cycle, there was an increase from 62.8 to 74.5 . In this study, data obtained from individual and classical learning completeness criteria, were as follows: as many as 30 of 35 students or $85.72 \%$ who scored above 70 or equal to 70 , and 5 other students or equal to $14.28 \%$ scored below 70 Based on observations of student activities, the percentage of students who were active in the first cycle was $48.2 \%$ with the number of students 17 from 35 students, and students who were active in the second cycle by $80 \%$ with the number of students 28 out of 35 students.
\end{abstract}

Keyword: learning outcomes, learning activities 


\section{Introduction}

Learning is done to teach students who act as subjects of learning. In principle, teaching and learning activities are to make students active in learning so they can shape the meaning and understanding of the learning itself so that it can improve student learning outcomes according to the minimum completeness criteria (KKM) that have been determining. In learning, activeness of students will be able to foster student motivation, not just sit still and let learning go by and can develop students' willingness and learning abilities. However, the reality is that learning becomes neglected as the demands for material fulfilment must be mastered by students (Suprihatin, 2015).

Biology is one of the subjects taught in high school (SMA) which contains many concepts that must be mastered by students. This makes the teacher focused only on the fulfilment of material that must be mastered by students in the learning that was delivered so that student activities often become neglected (Suprihatin, 2015). In the initial observations made, it was stated that previously learning had been applied using a model that is cooperative Talking Chips type on the subject matter of Biodiversity. However, this learning has not been able to maximise student activities, through questionnaires conducted indicating that $60 \%$ of students said Biology was learning with the cooperative model of Talking Chips Biodiversity material that has been done less actively involved students because students did not understand the mechanism of learning. The information is also supported by student learning outcomes, it is known that only 18 out of 32 students who passed the maximum completeness criteria (KKM) 70 with a classical completeness percentage of $56.2 \%$ because at least the items that can be answered correctly by students during the exam.

From the explanation above, it can be seen that there are several problems in Biology learning that are carried out, including: (1) The learning model used is not yet effective, (2) In the implementation of the learning process students do not involve themselves because students do not understand the mechanism of learning. ) Student learning outcomes are low because there are few items that can be answered correctly by students.

To solve this problem, the improvement of Talking Chips type cooperative learning was re-implemented by looking at the shortcomings that occurred in previous learning. The use of Talking Chips type cooperative learning model is expected to be able to encourage students to play an active role in learning so that student learning outcomes will increase. Talking Chips type cooperative learning is able to make students play an active role in group learning because in its application each member in the study group will get the same opportunity to be able to give opinions and listen to the views and thoughts of other group members. Talking Chips type cooperative learning also ensures that all members of the group have the opportunity to speak and express opinions (Sari, 2013).

Referring to the strength of the Talking Chips type cooperative learning model as described in the previous presentation, Biology learning was conducted on the subject matter of Biodiversity by applying the Talking Chips type cooperative learning model and measuring the application of the model to improve the learning outcomes of Biology and class X MIA1 activities. in Medan 10 Public High School Academic Year 2018/2019.

\section{Research Methods}

This research was conducted in class $\mathrm{X}$ MIA1SMA Negeri 10 Medan in the odd semester T.P. 2018/2019 which is located at Jl. Tilak No. 108, Sei Rengas I, Medan City 20214. This research lasts for 3 (three) months, from July to September 2018.

The subjects of this study were 35 students of class X MIA1 Medan 10 High School. This research is included in classroom action research. Class action research (PTK) looks at learning activities in the form of an action that is deliberately raised and occurs in the classroom. Classroom action research was carried out through two cycles to see student learning outcomes during the teaching and learning process on biodiversity material by using cooperative learning models typing chips in class X MIA1 Medan 10 High School T.P 2018/2019. Classroom action research (PTK) consists of a series of four activities carried out in each cycle. Four main activities that exist in each cycle, namely (a) planning, (b) action, (c) observation, (d) reflection (Kunandar, 2011).

The step that will be taken by the researcher in connection with the research first is to observe the research partners, namely Medan 10 Public High School as a place of study to 
obtain the willingness of subject teachers and make direct observations in the class that will be the subject of research. After that, the researchers then prepared the instruments needed in collecting research data. Next is the implementation of learning by applying the cooperative learning type Talking Chips model. Researchers work with observers to collect data in accordance with the instrument during the learning process. The research instrument used was in the form of test questions and observation of student activities. The learning outcome test is in the form of multiple-choice cognitive tests of 30 questions with five answer choices (a, b, c, d and e) that meet the requirements according to the level of difficulty, power difference, test validity and test reliability. The test will be given twice, namely at the time of pretest and post-test each cycle.

Data collection activities take place for two meetings in each cycle. The number of cycles that occur is carried out in accordance with the achievement of indicators of success. After the data is collected, then data processing and analysis will be carried out and then the discussion of the results of the research is carried out by reviewing the actions that have been done and drawing conclusions.

Data analysis was carried out descriptively. Data is processed using the descriptive percentage formula (\%). To find out the completeness of individual learning, formulas are used:

$$
\mathrm{KI}=\frac{\mathrm{T}}{\mathrm{Tt}} \mathrm{x} 100 \%
$$

With the criteria: $0<\mathrm{KI}<70=$ students have not finished learning, $70 \leq \mathrm{KI} \leq 100=$ students have completed learning. To find out the completeness of student learning in a classical way, namely by calculating the percentage of students in the class who have thoroughly studied with:

$$
\mathrm{KS}=\frac{\mathrm{ST}}{\mathrm{N}} \times 100 \%
$$

Individual completeness is said to be achieved if the proportion of answers answered by students is correct is $\geq 70 \%$ and classical completeness is said to be achieved if in the class there are $\geq 85 \%$ of students who have achieved individual learning completeness (Somadayo, 2013)

\section{Result and Discussion}

\section{a. Result}

From the results of observations in cycles I and II, it can be seen that the average value of learning outcomes and student learning activities can be increased. Observations on learning outcomes can be seen in Table 1.

\begin{tabular}{|c|c|c|c|}
\hline No & $\begin{array}{c}\text { Learning } \\
\text { Outcomes } \\
\text { Test }\end{array}$ & $\begin{array}{c}\text { Student } \\
\text { Number }\end{array}$ & $\begin{array}{c}\text { Percenta } \\
\text { ge (\%) }\end{array}$ \\
\hline 1. & $\begin{array}{c}\text { Pretest cycle } \\
\text { I }\end{array}$ & 7 & 20 \\
\hline 2. & $\begin{array}{c}\text { Pretest cycle } \\
\text { II }\end{array}$ & 15 & 42,9 \\
\hline 3. & $\begin{array}{c}\text { Postest cycle } \\
\text { I }\end{array}$ & 23 & 65,7 \\
\hline 4. & $\begin{array}{c}\text { Postest cycle } \\
\text { II }\end{array}$ & 30 & 85,7 \\
\hline
\end{tabular}

Table 1. Student learning outcomes

It can be seen that when the pretest was carried out in the first cycle, the percentage of students who completed it was $20 \%$ with the number of students as many as 7 students with an average score of 40.6. Then doing talking learning cooperative chips type, the percentage of students completeness when answering posttest questions is $65.7 \%$ with the number of students completing is 23 students and those who do not complete are 12 students and the average value is 68.6. At the time of the second cycle pretest, the percentage of completeness of students was $42.9 \%$ with the number of students completed as many as 15 students and those who did not complete as many as 20 people with an average score of 62.8. In the posttest cycle II, the percentage of student completeness was $85.7 \%$, the number of students who completed was 30 students and those who did not complete as many as 5 students with an average value obtained was 74.5. So from that can be seen an increase in student learning outcomes from cycle I to cycle II by using cooperative learning models talking chips type in biodiversity material in class $\mathrm{X}$ MIA1 Medan 10 High School. The results of observations on student activities can be seen in Table 2. 
Table 2. Student Activity

\begin{tabular}{|l|l|c|c|c|c|}
\hline \multirow{2}{*}{ No } & & \multicolumn{2}{|c|}{ Cycle I } & \multicolumn{2}{c|}{ Cycle II } \\
\cline { 3 - 6 } & $\begin{array}{c}\text { Criteri } \\
\mathbf{a}\end{array}$ & $\begin{array}{c}\text { Student } \\
\text { Numbe } \\
\mathbf{r}\end{array}$ & $\mathbf{\%}$ & $\begin{array}{c}\text { Student } \\
\text { Number }\end{array}$ & \% \\
\hline 1. & $\begin{array}{l}\text { Very } \\
\text { Active }\end{array}$ & 1 & 2,87 & 2 & 5,7 \\
\hline 2. & Active & 16 & 45,7 & 26 & $\begin{array}{c}74, \\
28\end{array}$ \\
\hline 3. & $\begin{array}{l}\text { Active } \\
\text { Enough }\end{array}$ & 16 & 45,7 & 7 & 20 \\
\hline 4. & $\begin{array}{l}\text { Not } \\
\text { Active }\end{array}$ & 2 & 5,71 & - & 0 \\
\hline
\end{tabular}

Can be seen an increase in student activity from cycle I to cycle II. In learning cycle I the percentage of students who are very active in learning is $2.87 \%$ with the number of students as much as 1 student, an increase in the second cycle is $5.71 \%$ with the number of students as many as 2 people. The percentage of active students in the first cycle was $45.71 \%$ with many students, namely 16 people, in the second cycle an increase in the number of students was as many as 26 students with a percentage of $74.28 \%$. For the percentage of students who were quite active in the first cycle, there were 16 people with a percentage of $45.71 \%$ in the second cycle decreased to $20 \%$ with the number of students 7 people. And for students who are not active in the first cycle as many as 2 people with a percentage of $5.71 \%$ in the second cycle, there is a decrease in the number of students who are inactive at $0 \%$ because there are no students who are not active in the second cycle of learning.

\section{b. Discussion}

From the average pretest results, it can be seen that the student learning outcomes before using the cooperative learning model of the Talking Chips type are low, this occurs because of the small number of students who correctly answer the items given. The KKM standard (minimum completeness criteria) in Medan 10 Public High School is 70 .

After knowing the students' initial abilities with pretesting, learning was carried out with a cooperative model of talking chips type in biodiversity material with regard to weaknesses in previous learning. At the end of the study given 15 posttest of multiple-choice questions, the average posttest score results obtained in the first cycle were 68.6 with the percentage of students completing was $65.7 \%$ and the number of students was 23 people. While students who did not complete were 12 people with a percentage of $34.2 \%$. This shows that classical completeness has not been achieved, namely $85 \%$ of students who complete. Can also be seen in the results of observations of student activities in the first cycle during learning carried out, showing the percentage of active and very active students by $48.2 \%$ with the number of students as many as 17 people. Then the improvement of learning is done in cycle II.

In the second cycle, Talking Chips type cooperative learning was carried out by paying attention to weaknesses in cycle I. Before the learning was carried out, first the learning outcomes test was given in the form of 15 pretest multiple questions. In the preliminary learning activities, the second cycle is not different from the first cycle. In the core learning activities, the researcher presents a biodiversity learning video that is not raised during the cycle I core learning activities. When the video is shown, students are very enthusiastic to watch, and after that, the researcher holds a question and answer session. to students regarding the video.

The video presentation of learning and question and answer conducted made students have the initial knowledge and description of the material to be studied so that when the discussion answered the LKPD students were easier to answer because they already had initial knowledge. This has a good effect when students answer the posttest questions in the second cycle, the number of questions answered correctly by students at the pretest increases more than the pretest so that the number of students who pass the standard for maximum completeness criteria also increases. The closing activities of learning are not much different from the first cycle, in the first cycle the researchers together with students to draw conclusions, but in the second cycle, the researchers guided students to conclude learning without the help of researchers.

\section{Conclusion}

Student learning outcomes increase from cycle I to cycle II. The percentage of students completed in the first cycle when pretesting was $20 \%$ to $65.7 \%$. The percentage of students completed in the second cycle when pretesting was $42.9 \%$ to $85.7 \%$ during posttest. The learning activities of students of class X MIA1 Medan 10 High School by applying Talking Chips type cooperative learning on biodiversity material increased from $48.28 \%$ in the first cycle 
to $80 \%$ in the second cycle. This means that learning using the cooperative model type Talking Chips can increase the activity of students of class X MIA1 Medan 10 High School.

\section{References}

Arikunto, S., (2008), Dasar-dasar Evaluasi Pendidikan, Bumi Aksara, Jakarta

Arikunto, S., (2012), Penelitian Tindakan Kelas, Bumi Aksara, Jakarta

Aziz, M., Tarmedi, E. dan Untung, S., (2015), Hubungan Antara Kelompok Teman Sebaya dengan Prestsi Belajar Siswa SMKN. Journal of Mechanical Engeenering Education, 2(02)

Gredler, M.E., (2011), Learning and Instruction : Teori dan Aplikasi Edisi Keenam, Kencana, Jakarta

Haeruddin, A., Karmila, (2017), Perbandingan Model Pembelajaran Kooperatif Tipe Talking Chips dengan Snowball Throwing terhadap Hasil Belajar Siswa Pada Mata Pelajaran Biologi Kelas XI IPA MAN I Sinjai Utara, Skripsi, Prodi Pendidikan Biologi Fakultas Tarbiyah dan Keguruan UIN Alauddin, Makassar.

Kemendikbud, (2016), Permendikbud Nomor 20 Tahun 2016 tentang Standar Kompetensi Lulusan Pendidikan Dasar dan Menengah, Kementrian Pendidikan dan Kebudayaan, Jakarta

Kemendikbud, (2016), Permendikbud Nomor 21 Tahun 2016 tentang Standar Isi Pendidikan Dasar dan Menengah, Kementrian Pendidikan dan Kebudayaan, Jakarta

Kunandar, (2011), Langkah Mudah Penelitian Tindakan Kelas sebagai
Pengembangan Profesi Guru, Raja Grafindo, Jakarta

Kunandar, (2013). Penilaian Autentik (Penilaian Hasil Belajar Peserta Didik Berdasarkan Kurikulum 2013 Edisi 1. Rajawali Pers, Jakarta

Mahabbati, Aini, (2012), Analisa Teori Belajar Sosial Bandura Mengenai Gangguan Perilaku Agresif pada Anak, Jurnal Pendidikan Khusus IX, 02:1-12

Radja, P., Soetjipto, B., dan Amiruddin, A., (2017), Implementasi Model Pembelajaran Kooperatif Talking Chips dan Fan-n-Pick dalam Meningkatkan Motivasi dan Hasil Belajar IPS, Jurnal Pendidikan, 2(09):1196-1216

Rofiq, M., (2010), Pembelajaran Kooperatif (Cooperative Learning) dalam Pengajaran Pendidikan Agaman Islam, Jurnal Falafisa, 01(01):114

Sanjaya, Wina, (2009), Strategi Pembelajaran Berorientasi Standard Proses Pendidikan, Kencana, Jakarta

Sari, N., Armiati, dan Susanti, D., (2013), Perbedaan Hasil Belajar Siswa Menggunakan Model Pembelajaran Kooperatif Course Review Horey dengan Pembelajaran Konvensional pada Mata Pelajaran Ekonomi Siswa Kelas X SMA Adabiah Padang. Jurnal Ekonomi, 01(02):135-144

Sari, Gusliana, (2017), Penerapan Model Pembelajaran Talking Chips dalam Meningkatkan Hasil Belajar Siswa pada Materi Asam Basa di SMAN 01 Meureubo Aceh Barat, Skripsi, Prodi Pendidikan Kimia Fakultas Tarbiyah UIN Ar-Raniry Darussallam, Banda Aceh

Silberman, M.L., (2006), Active Learning : 101 Cara Belajar Siswa Aktif. Nusamedia, Bandung. 
Somadayo, Samsu, (2013), Penelitian Tindakan Kelas, Graha Ilmu, Yogyakarta

Suprihatin, Siti, (2015), Upaya Guru dalam Meningkatkan Motivasi Belajar Siswa, Jurnal Pendidikan Ekonomi, 03(1):82

Syarifuddin, Ahmad, (2011), Penerapan Model Pembelajaran Kooperatif dan Faktor-faktor yang Mempengaruhinya, Fakultas Tarbiyah IAIN Raden Fatah Palembang. 26(01)

Wahyuni, S., Hasdin, dan Nurvita, (2014), Penerapa Metode Kerja Kelompok Untuk Meningkatkan Hasil Belajar IPS pada Siswa Kelas V di SDN 15 Biau, Jurnal Kreatif Takulado Online, 05(03):210-223

Wahyuni, (2016), Pembelajaran Kooperatif Bukan Pembelajaran Kelompok Konvensional, Jurnal, 03(01):37-43

Wibawa, L., Wirya, N., dan Tegeh, M.,, (2016), Pengaruh Model Pembelajaran Talking Chips Terhadap Hasil Belajar Siswa Kelas V, e-Journal PGSN Universitas Pendidikan Ganesha, 01(01):1-11

Yanda, A., Asrul, dan Yurnetti., (2013), Pengaruh Penggunaan Teknik Talking Chips Terhadap Hasil Belajar IPA Fisika Siswa Kelas VII SMPN 1 IV Jurai Kabupaten Pesisir Selatan, Jourrnal of Pillar Physics Education, 01:97-103. 